are reluctant to take this step, which frustrates the attainment of an objective they themselves desire.

This small series is reported because we believe that jaw wiring followed by the fitting of a waist cord could be a valuable treatment for severe obesity. Unlike the bypass procedures it is inexpensive and safe. Only one of our patients (case 4, table I) seems unwilling to tolerate the waist cord: the others are maintaining their weight at a level just below that at which it is uncomfortable. Several patients have volunteered the observation that they would have gained weight on holiday had it not been for the waist cord, and they are anxious that it should not be removed. This result supports the hypothesis that such factors as the tightness of clothing are important in regulating body weight. ${ }^{15}$

\author{
References \\ 1 James WPT, ed. Research on obesity: a report of the DHSS/MRC study \\ group. London: HMSO, 1976:94. \\ 2 Bray GA, ed. Obesity in America. Bethesda Md.: US Department of \\ Health Education and Welfare, 1979. (NIH Publication No. 79-358). \\ ${ }^{3}$ Garrow JS. Energy balance and obesity in man. Amsterdam: Elsevier/ \\ North Holland, 1978.
}

${ }^{4}$ Mason EE, Printen KJ, Blommers TJ, Lewis JW, Scott DH. Gastric bypass in morbid obesity. Am $\mathcal{F}$ Clin Nutr $1980 ; 33: 395-405$.

5 O'Leary JP. Overview: Jejunoileal bypass in the treatment of morbid obesity. Am F Clin Nutr $1980 ; 33: 389-94$.

${ }^{6}$ Pilkington TRE, Gazet J-C, Ang L, Kalucy RS, Crisp AH, Day S. Explanation for weight loss after ileojejunal bypass in gross obesity. Br Med f 1976; : 1504-5.

7 Garrow JS. Dental splinting in the treatment of hyperphagic obesity. Proc Nutr Soc 1974;33:29A.

${ }^{8}$ Drenick EJ, Hargis HW. Jaw wiring for weight reduction. Obesity $\&$ Bariatric Medicine $1978 ; 7 \cdot 210-3$.

${ }^{9}$ Fordyce GL, Garrow JS, Kark AE, Stalley SF. Jaw wiring and gastric bypass in the treatment of severe obesity. Obesity $\mathcal{E}$ Bariatric Medicine $.1979 ; 8: 14-7$.

10 Garrow JS, Durrant ML, Mann S, Stalley SF, Warwick P. Factors determining weight loss in obese patients in a metabolic ward. International fournal of Obesity, 1978;2:441-7.

11 Wood GD. Early results of treatment of the obese by a diet regimen enforced by maxillomandibular fixation. F Oral Surg 1977;35:461-4.

12 Rodgers S, Burnet R, Goss A, et al. Jaw wiring in the treatment of obesity Lancet $1977 ; \mathrm{i}: 1221-3$.

${ }^{13}$ Harding PE. Jaw wiring for obesity. Lancet 1980 ;i :534-5.

14 Castelnuovo-Tedesco P, Buchanan DC, Hall HD. Jaw wiring for obesity. General Hospital Psychiatry 1980 ;2:156-9.

15 Garrow JS, Stalley SF. Cognitive thresholds and human body weight. Proc Nutr Soc 1977;36:18A.

(Accepted 5 fanuary 1981)

\title{
Treatment of severe aplastic anaemia with antilymphocyte globulin or bone-marrow transplantation
}

\author{
BRUNO SPECK, ALOIS GRATWOHL, CATHERINE NISSEN, URS LEIBUNDGUT, \\ DONATELLA RUGGERO, BRUNO OSTERWALDER, HANS PETER BURRI, \\ PIERRE CORNU, MICHEL JEANNET
}

\begin{abstract}
Fifty-three patients with severe aplastic anaemia were admitted to this hospital between January 1976 and June 1980, of whom three arrived in terminal condition and died before treatment for their basic disease could be given. Thus 50 patients were treated and evaluated in a prospective study according to one protocol. Eighteen patients with an HLA-identical sibling underwent bonemarrow transplantation with the aim of achieving haematopoietic chimerism. Thirty-two patients without an HLA-identical sibling were given antilymphocyte globulin with or without an infusion of HLA-haplotypeidentical marrow. All these 32 patients received low-dose androgens after the procedure. In the first group eight
\end{abstract}

Division of Haematology, Department of Internal Medicine,

Kantonsspital, University of Basle, Switzerland

BRUNO SPECK, MD, professor of haematology

ALOIS GRATWOHL, MD, senior resident in haematology

CATHERINE NISSEN, MD, research fellow

URS LEIBUNDGUT, MD, research fellow

BRUNO OSTERWALDER, MD, senior resident in haematology

PIERRE CORNU, MD, senior resident in haematology (present address : Hôpital de la Providence, Vevey, Switzerland)

DONATELLA RUGGERO, MD, research fellow (present address: division of haematology, University Hospital, Bologna, Italy)

Blood Bank, Kantonsspital, University of Basle, Switzerland HANS PETER BURRI, MD, head

Division of Transplantation Immunology, Hôpital Cantonal, Geneva, Switzerland

MICHAEL JEANNET, MD, assistant professor patients $(44 \%)$ survived. In the two other groups, 22 patients survived $(69 \%)$, of whom 20 were completely self-sustaining $(63 \%)$. Engraftment and graft-versushost disease did not occur in the group who received antilymphocyte globulin and haploidentical marrow, and the haematopoietic reconstitutions in these patients were all autologous.

These results confirm the efficacy of antilymphocyte globulin in the treatment of severe aplastic anaemia and show that such treatment is at least as good as bonemarrow transplantation. Its mechanism of action remains unknown, but most patients with aplastic anaemia have a pool of haematopoietic stem cells able to repopulate the marrow after this type of treatment.

\section{Introduction}

The potential usefulness of antilymphocyte globulin followed by allogeneic marrow infusion in treating aplastic anaemia was first reported in $1970 .{ }^{1}$ In 1977 we reported the results in 29 patients with severe aplastic anaemia treated with antilymphocyte globulin with or without marrow infusion. ${ }^{2}$ The rationale ${ }^{3}$ and experimental ${ }^{4}$ and clinical $^{5}$ basis for this therapeutic approach to aplastic anaemia have been outlined. Despite these early results doubts remained about the usefulness of antilymphocyte globulin because of possible patient selection. We therefore began a study in 1976 to compare prospectively bonemarrow transplantation and treatment with antilymphocyte globulin alone or followed by bone-marrow infusion. All admitted patients with severe aplastic anaemia without exception were treated according to one protocol. They were classified 
into three groups depending on the availability and histocompatibility of a family donor. All three groups were comparable in age, transfusion history, severity of pancytopenia, interval between diagnosis and treatment, previous treatment with androgens, and all factors known to influence the prognosis ${ }^{6}$ of severe aplastic anaemia and the fate of haematopoietic grafts. $^{7-9}$ We report here the results obtained.

\section{Patients and methods}

We studied all the patients referred to Kantonsspital Basle between January 1976 and June 1980. All had severe aplastic anaemia and fulfilled at least two of the three blood criteria and the criterion for bone-marrow histology. ${ }^{6}$ They were classified on admission according to the criteria shown in table I. All patients surviving the time required for histocompatibility testing were treated. Most of them had been referred from other medical centres, where conventional treatment has been tried, and so the interval between diagnosis and treatment varied widely.

All three groups were comparable in age, aetiology, previous treatment, and blood counts (table II). They were also comparable in their transfusion history, but in most of the referred patients exact data were difficult to obtain. Three patients had not received transfusions (one in each group), while the others had received many transfusions and depended on regular substitution of blood components. Three patients (one in each group) had a long history of aplastic anaemia. This had remitted initially but they were sent to us in relapse. Three patients were in terminal stage on arrival and died despite maximal

TABLE I-Clissification criteria and treatment

\begin{tabular}{ccc}
\hline Group & Criteria & Treatment \\
\hline A & $\begin{array}{c}\text { HLA-A, B, Dr identical } \\
\text { sibling donor, mixed } \\
\text { leucocyte culture not } \\
\text { reactive } \\
\text { HLA-haploidentical, ABO- } \\
\text { identical, cross-match } \\
\text { negative family donor }\end{array}$ & $\begin{array}{c}\text { Cyclophosphamide } 50 \mathrm{mg} / \mathrm{kg} \times 4+\text { bone- } \\
\text { marrow transplantation }\end{array}$ \\
B & $\begin{array}{c}\text { Antilymphocyte globulin } 40 \mathrm{mg} / \mathrm{kg} \times 4+ \\
\text { bone-marrow infusion } \\
\text { Norethandrolone } 0.5-1 \mathrm{mg} / \mathrm{kg} / \text { day by } \\
\text { mouth } \\
\text { Antilymphocyte globulin } 40 \mathrm{mg} / \mathrm{kg} \times 4 \\
\text { Norethandrolone } 0.5-1 \mathrm{mg} / \mathrm{kg} / \mathrm{day} \text { by } \\
\text { mouth }\end{array}$ \\
C & No donor & \\
\hline
\end{tabular}

support before treatment could be given. The remaining 50 patients were allocated to one of three groups.

Group $A$ comprised 18 patients (nine male, nine female) who had an HLA-identical sibling donor. They were all given four doses of $50 \mathrm{mg}$ cyclophosphamide/kg followed by a marrow graft consisting of a median of $3.75 \times 10^{8}$ (range 2.9-13.0 $\left.\times 10^{8}\right)$ nucleated marrow cells $/ \mathrm{kg}$. The median age was 18 (range 4-29) years. In seven cases there was a major $\mathrm{ABO}$ barrier that required plasma exchange. The initial seven patients were given only marrow. The remaining 11 were given unirradiated peripheral blood buffy coat from four units of blood from the marrow donor on each of five successive days after bone-marrow transplantation. The first 14 patients were given methotrexate ${ }^{7}$ for prophylaxis against graft-versus-host disease, while the last four were given cyclosporin $A .^{10}$

Group $B$ comprised 20 patients ( 16 male, four female) who had no HLA-identical sibling donor but for whom an HLA-haplotypeidentical, ABO-compatible family donor was available. They were given antilymphocyte globulin $40 \mathrm{mg} / \mathrm{kg}$ on each of four successive days followed by a marrow infusion consisting of a median of $2.3 \times 10^{8}$ (range 1.2-5.5 $\times 10^{8}$ ) nucleated marrow cells $/ \mathrm{kg}$. This was followed by oral norethandrolone $0.5-1.0 \mathrm{mg} / \mathrm{kg} / \mathrm{day}$ for four to six months, after which the dose was gradually reduced. The median age was 22 (range 10-49) years.

Group $C$ comprised 12 patients (seven male, five female) who had no family donor available, preformed antibodies against all potential donors, or major $\mathrm{ABO}$ barriers or whose potential donor was ill and at high risk for anaesthesia. They were treated with four doses of antilymphocyte globulin $40 \mathrm{mg} / \mathrm{kg}$ alone followed by norethandrolone, as in group B. The median age was 23 (range 7-37) years.

Antilymphocyte globulin-Equine antilymphocyte globulin from the same horse was used throughout the study (Schweiz Serum- und Impfinstitut, Berne). The horse was immunised every six weeks by human thoracic-duct lymphocytes. In patients who relapsed rabbit antithymocyte globulin (RIV (Holland)) was given. Both preparations prolong skin allograft survival in rhesus monkeys.

\section{Results}

Table III shows the results of treatment and figure 1 compares survival in the three groups. Table IV shows the blood counts in survivors.

Group $A(\mathrm{n}=18)$-Eight patients survived for from six months to over four and a half years after transplantation $(44 \%)$. Seven were

TABLE II-Clinical details of patients in the three groups

\begin{tabular}{|c|c|c|c|c|c|c|c|c|c|}
\hline \multirow[b]{2}{*}{ Group } & \multirow{2}{*}{$\begin{array}{l}\text { No in } \\
\text { group }\end{array}$} & \multirow{2}{*}{$\begin{array}{l}\text { Median age (years) } \\
\text { (and range) }\end{array}$} & \multirow[b]{2}{*}{ Sex } & \multirow[b]{2}{*}{ Aetiology } & \multirow{2}{*}{$\begin{array}{l}\text { Median interval } \\
\text { between diagnosis } \\
\text { and treatment } \\
\text { (months) } \\
\text { (and range) }\end{array}$} & \multirow{2}{*}{$\begin{array}{l}\text { No receiving } \\
\text { androgens }\end{array}$} & \multicolumn{3}{|c|}{$\begin{array}{c}\text { Median blood counts on admission } \\
\left(\times 10^{\circ} / 1\right) \text { (and range) }\end{array}$} \\
\hline & & & & & & & Reticulocytes & Granulocytes & Thrombocytes \\
\hline A & 18 & $18(4-29)$ & $\begin{array}{l}9 \mathrm{M}, \\
9 \mathrm{~F}\end{array}$ & $\begin{array}{l}15 \text { idiopathic } \\
2 \text { posthepatitis } \\
1 \text { benzene (?) }\end{array}$ & $3.5(1-72)$ & 9 & $4 \cdot 4(0-100)$ & $0.2(0-1.9)$ & $3(1-25)$ \\
\hline B & 20 & $22(10-49)$ & $\begin{array}{l}16 \mathrm{M}, \\
4 \mathrm{~F}\end{array}$ & $\begin{array}{l}14 \text { idiopathic } \\
3 \text { toxic ( } 1 \text { chloramphenicol, } \\
1 \text { benzene, } 1 \text { amidopyrine) } \\
2 \text { posthepatitis } \\
1 \text { Fanconi }\end{array}$ & $6(1-28)$ & 11 & $8.9(0-38)$ & $0.25(0-1 \cdot 2)$ & $6(0-16)$ \\
\hline C & 12 & $23(7-37)$ & $\begin{array}{l}7 \mathrm{M}, \\
5 \mathrm{~F}\end{array}$ & $\begin{array}{l}10 \text { idiopathic } \\
2 \text { toxic ( } 1 \text { chloramphenicol, } \\
1 \text { benzene) }\end{array}$ & $5(1-168)$ & 6 & $5(0-67)$ & $0.15(0-0.6)$ & $7 \cdot 5(2-20)$ \\
\hline
\end{tabular}

TABLE III-Results of treatment

\begin{tabular}{ccccccc}
\hline Group & $\begin{array}{c}\text { No of } \\
\text { patients }\end{array}$ & $\begin{array}{c}\text { No of } \\
\text { deaths }\end{array}$ & Cause of death & No of \\
survivors
\end{tabular}

* Nineteen were evaluable as one was lost to follow-up.

t One after antithymocyte globulin and haploidentical marrow. 
haematopoietic chimeras and one had complete autologous haematopoietic reconstitution. Of the 10 deaths, four were caused by rejection and infection and six by graft-versus-host disease and interstitial pneumonia. Of the first seven patients, who received only marrow, three survived, two as chimeras and one with autologous reconstitution. Of the four deaths, three were due to rejection and infection and one to graft-versus-host disease and interstitial pneumonia. All 11 patients given marrow and buffy-coat infusions showed prompt engraftment. One died early from infection. Six patients given prophylactic methotrexate developed moderate to severe graft-versushost disease, which caused the death of four in conjunction with

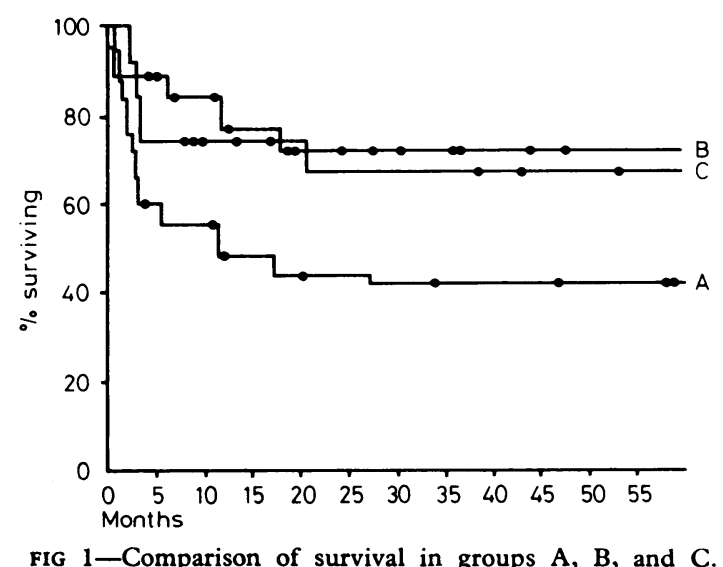

FIG 1-Comparison of survival in groups $\mathrm{A}, \mathrm{B}$, and $\mathrm{C}$ $=$ Surviving patient. responder an HLA-identical sibling donor became available one year after the initial treatment. She received a graft but died from chronico graft-versus-host disease and infection. Thus of the four deaths in this group, three were caused by cerebral haemorrhage due to alloimmunisation with refractoriness to all available platelet support and one by graft-versus-host disease after an allogeneic marrow graft.

\section{Discussion}

Despite optimal supportive care, the outlook for patients with? severe aplastic anaemia who receive conventional treatment is $\overrightarrow{\vec{F}}$ still poor. In a large prospective study ${ }^{6}$ only $25 \%$ of the patients $\stackrel{\text { ? }}{+}$ survived regardless of whether they were given androgens but $\frac{}{2}$ $57 \%$ of the patients treated with bone-marrow transplantation $\frac{\bar{F}}{\bar{N}}$ survived. Many workers in the field therefore think that treat- $\frac{\rho}{\sigma}$ ments aiming at complete haematopoietic chimerism are the $\stackrel{\mathbb{\Omega}}{2}$ only rational approach to severe aplastic anaemia. ${ }^{11}$ Even with $ڤ$ an HLA-identical sibling, however, results need to be improved. In the most recent multicentre study, using this approach in $144 \stackrel{\circ}{\circ}$ patients, one-year survival was $44 \% .^{9}$ This is identical with the $\vec{\omega}$ results achieved in our group of patients, in whom the aim was $\stackrel{\odot}{\circ}$ haematopoietic chimerism. These results are not optimal, and in 3 addition it must be remembered that $10-20 \%$ of the surviving patients suffer from chronic graft-versus-host disease. Much hope came from the initial studies with total lymphoid irradia- of tion used in conjunction with cyclophosphamide for con- $\mathcal{S}$ ditioning, ${ }^{12}$ which yielded high engraftment rates and a low ${ }_{\infty}$ incidence of graft-versus-host disease. These data came from children, however, and could not be confirmed in adults. ${ }^{13}$

TABLE IV-Median blood counts (and ranges) $\left(\times 10^{9} / l\right)$ in surviving patients at last measurement made during follow-up

\begin{tabular}{|c|c|c|c|c|c|c|}
\hline Group & $\begin{array}{l}\text { No } \\
\text { surviving }\end{array}$ & $\begin{array}{l}\text { No self- } \\
\text { sustaining }\end{array}$ & $\underset{(\mathrm{g} / \mathrm{dl})}{\text { Haemoglobin }}$ & Reticulocytes & Granulocytes & Thrombocytes \\
\hline $\mathbf{A}$ & 8 & 8 & \multirow{3}{*}{$\begin{array}{l}13 \cdot 75 \\
(10 \cdot 3-15 \cdot 9) \\
14 \cdot 3 \\
(8 \cdot 8-15 \cdot 9) \\
10 \cdot 5 \\
(8 \cdot 2-15 \cdot 6)\end{array}$} & \multirow{3}{*}{$\begin{array}{l}50 \\
(22-98) \\
47 \cdot 5 \\
(8 \cdot 8-172 \cdot 0) \\
54 \\
(6-70)\end{array}$} & \multirow{3}{*}{$\begin{array}{l}4 \\
(2 \cdot 1-7 \cdot 3) \\
1 \cdot 7 \\
(0 \cdot 6-3 \cdot 3) \\
1 \cdot 9 \\
(0 \cdot 9-2 \cdot 2)\end{array}$} & \multirow{3}{*}{$\begin{array}{l}250 \\
(103-283) \\
90 \\
(10-340) \\
40 \\
(9-190)\end{array}$} \\
\hline B & 14 & 13 & & & & \\
\hline C & 8 & 7 & & & & \\
\hline
\end{tabular}

interstitial pneumonia or overwhelming infection. The two survivors suffered from disabling chronic graft-versus-host disease. Of the four patients given cyclosporin $\mathbf{A}$ instead of methotrexate as prophylaxis against graft-versus-host disease, three survived: one patient died from generalised cytomegalovirus infection while the others remained alive and well without signs of graft-versus-host disease.

Group $B(\mathrm{n}=20)$-One patient was lost to follow-up at two months, but of the 19 evaluable patients, 14 survived $(74 \%)$. Thirteen of these had completely self-sustaining haematopoiesis. One needed occasional red-cell transfusions. All continued taking low-dose androgens (norethandrolone $5-10 \mathrm{mg} /$ day). They were all leading a normal life and there were no chronic problems. Five patients died, two from massive intracranial haemorrhage 24-48 hours after marrow infusion. One showed no response and died from an acute septic infection in another hospital. Three of the initial responders relapsed after stopping the androgens and were given rabbit antithymocyte globulin. One went into complete remission again, but two died from cerebral haemorrhage due to alloimmunisation and complete refractoriness to all platelet donors that were available.

Group $C(\mathrm{n}=12)$-Eight patients survived $(67 \%)$, seven with selfsustaining haematopoiesis. All continued to receive androgens (norethandrolone $5-10 \mathrm{mg} /$ day). One relapsed but responded to a second course of treatment with rabbit antithymocyte globulin. A second relapse occurred, and this patient then remained transfusion dependent. Two patients showed no response to antilymphocyte globulin alone but remained alive. One of them was treated with rabbit antithymocyte globulin followed by infusion of HLA-haplotypeidentical marrow three years later. He responded with complete haematopoietic recovery and was subsequently treated by phlebotomies for iron overload from previous transfusions. For the other non-
Virtually all patients have received many transfusions when they are referred to us. Such sensitisation seems to be the most common cause of graft rejection. ${ }^{7}$ If patients receive a transplant before they need transfusions results are significantly better. ${ }^{14}$ New hope for preventing graft-versus-host disease comes now $\frac{5}{3}$ from prophylactic cyclosporin A. In the four patients in whom we used this drug instead of methotrexate, no severe graftversus-host disease was seen. Because of the small number of patients, however, conclusive statements are impossible. Never- $\frac{9}{3}$ theless, with our experience with bone-marrow transplantation $N$ in acute leukaemia, when we saw no severe graft-versus-host disease in 10 successive patients treated with cyclosporin $A$, we think that this is a promising approach to preventing such disease. ${ }^{15}$ The value of the drug in bone-marrow transplantation $N$ using HLA non-identical donors has not yet been established. $\omega$

The results achieved in groups $B$ and $C$ support further our assumption that in most cases the pathogenetic mechanism in severe aplastic anaemia is a disturbed maturation in the haemato- $\mathbb{D}$ poietic precursor cell compartment rather than a defect at the + level of the pluripotent stem cell itself. ${ }^{5}$ The autologous recon- $\frac{0}{0}$ stitutions seen after treatment with antilymphocyte globulin and $\frac{\vec{D}}{d}$ androgens with or without marrow infusion are usually less $\frac{\rho}{\mathbb{D}}$ complete than haematopoietic chimerism. In particular, median $\cong$ platelet and granulocyte counts are lower than in chimeras. Furthermore, it takes much longer for these patients to become 8 self-sustaining and independent of transfusions (fig 2). Another concern is androgen dependence. Until 1978 we completely 
stopped androgens as soon as remission was reached but saw three relapses within two months. One patient responded to rabbit antithymocyte globulin and was in complete remission taking continuous androgens one year after the second treatment. Two patients died from cerebral haemorrhage after antithymocyte globulin due to severe alloimmunisation and refractoriness to all available platelet donors. Subsequently we kept our patients on low-dose androgens-that is, norethandrolone $10 \mathrm{mg}$ daily or, later, every other day. With this dose we did not see any serious side effects or relapses. Intriguingly, even in complete haematological remission in-vitro growth of haematopoietic precursor cells (BFU-E, CFU-E, and GM-CFU-C) is appreciably decreased. 10 Adding autologous peripheral mononuclear cells to the marrow cultures has a strong inhibiting effect. ${ }^{18}$ This phenomenon potentially indicates latent disease. Many of our patients remained in complete autologous remission for from four to over seven years, so this laboratory phenomenon may not necessarily imply that they still have life-threatening disease.

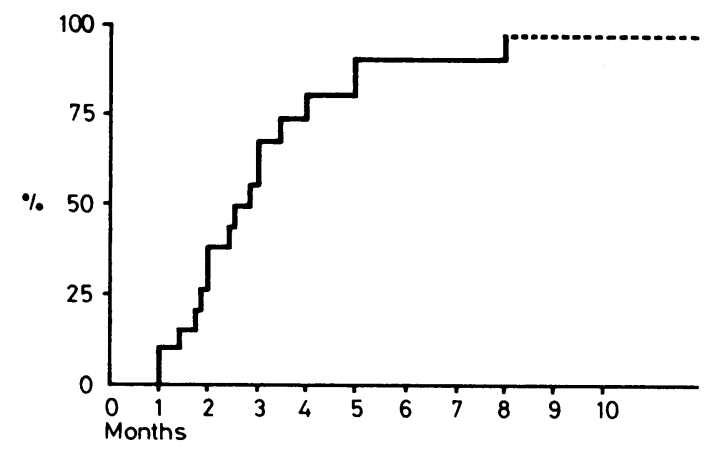

FIG 2-Time required in groups $B$ and $C(n=13$ and $n=6$ respectively) until patients self-sustaining and transfusion independent.

The role of marrow infusion was obvious in experimental benzene aplasia in rabbits where antilymphocytic serum alone was ineffective. ${ }^{5}$ Clinically, there was no significant difference between groups $B$ and $C$, and we do not know whether the marrow infusion added anything to the final result. Two patients died within 24-28 hours after marrow infusion from massive intracranial haemorrhage. Both had pronounced thrombocytopenia at the time of infusion. The most likely explanation for this phenomenon is that the heparin in the marrow might play a role in initiating haemorrhage. In the last 10 patients we therefore gave protamine sulphate immediately after the marrow to neutralise the heparin.

This prospective study of patients with severe aplastic anaemia has not solved all the questions about the pathogenesis and treatment of the disease. Nevertheless, it shows clearly that most of these patients have enough residual stem cells to repopulate the marrow and lead to haematopoietic remissions. This is extremely important for patients without an HLA-identical or syngeneic sibling donor. At present we cannot say whether antilymphocyte globulin really abrogates an autoimmune process in the marrow or makes stem cells sensitive to androgens in a non-specific way. Marrow infusion without the aim of engraftment has an experimental basis. ${ }^{3-5}$ We have continued to use it clinically because in our experience remissions have appeared to be more complete than with antilymphocyte globulins and androgens alone. Furthermore, one patient who did not respond to antilymphocyte globulin and androgens went into complete remission after HLA-haploidentical marrow was given in addition.

This study was supported by grants FOR AK 77 (2) and FOR LR 79 (2) from the Swiss Cancer League, 3.332.74 and 3.846.0.79 from the Swiss Science Foundation, and from the Swiss Public Health Service.

\section{References}

1 Mathe G, Amiel JL, Schwarzenberg L, et al. Bone marrow grafts in man after conditioning by antilymphocyte serum. Br Med $₹$ 1970;i:131-6.

2 Speck B, Gluckman E, Haak HL, von Rood JJ. Treatment of aplastic anaemia by antilymphocyte globulin with and without allogeneic bone marrow infusions. Lancet 1977 ;ii:1145-8.

${ }^{3}$ Speck B, Buckner CD, Cornu P, Jeannet M. Rationale for the use of ALG as sole immunosuppressant in allogeneic bone marrow transplantation for aplastic anemia. Transplant Proc 1976;8:617-23.

- Speck B, Kissling M. Successful bone marrow grafts in experimental aplastic anaemia using antilymphocyte serum for conditioning. Eur $\mathfrak{I}$ Clin Biol Res 1971;10:1047-51.

B Speck B, Cornu P, Nissen C, et al. On the pathogenesis and treatment of aplastic anemia. Experimental Hematology Today 1978;2:143-9.

- Camitta BM, Thomas ED, Nathan DG, et al. A prospective study of androgens and bone marrow transplantation for treatment of severe aplastic anemia. Blood 1979;53:504-14.

7 Storb R, Prentice RL, Thomas ED. Marrow transplantation for treatment of aplastic anemia, an analysis of factors associated with graft rejection. $N$ Engl f Med 1977;296:61-6.

8 Storb R, Prentice RL, Thomas ED. Treatment of aplastic anemia by marrow transplantation from HLA identical siblings. Prognostic factors associated with graft-versus-host disease and survival. $\boldsymbol{F}$ Clin Invest 1977;59:625-32.

- Bortin MM, Rimm AA. Allogeneic bone marrow transplantation for 144 patients with severe aplastic anemia. $\mathcal{F} A M A$ (in press).

10 Gratwohl A, Osterwalder B, Ruggero D, et al. Prophylaxis of graft versus host disease with Cyclosporin A. Blut 1980;41:180-1.

11 Storb R, Thomas ED. Human marrow transplantation. Transplantation $1979 ; 28: 1-3$.

12 Ramsay NKC, Kim T, Nesbit ME, et al. Total lymphoid irradiation and cyclophosphamide as preparation for bone marrow transplantation in severe aplastic anemia. Blood 1980;55:344-6.

13 Jansen J, Zwaan FE, Noordijk EM. Bone marrow transplantation in aplastic anemia using cyclophosphamide and total lymphoid irradiation. The Leiden Experience. Blut 1980;41:163-8.

14 Storb $R$. Decrease in graft rejection rate and improvement in survival after marrow transplantation for severe aplastic anemia. Transplant Proc 1979; 11 :196-8.

15 Speck B, Gratwohl A, Nissen C, et al. Cyclosporin-A for prophylaxis of graft-versus-host disease in clinical bone marrow transplantation. Experimental Hematology Today (in press).

${ }^{16}$ Nissen C, Cornu P, Gratwohl A, Speck B. Peripheral blood cells from patients with aplastic anemia in partial remission suppress growth of their own bone marrow precursors in culture. Br $\mathcal{F}$ Haematol 1980;45: 233-43.

(Accepted 18 December 1980)

THE BRAMBLE, OR BLACK-BERRY BUSH. It is so well known that it needs no description. The virtues thereof are as follows:

It is a plant of Venus in Aries. If any ask the reason why Venus is so prickly? Tell them it is because she is in the house of Mars. The buds, leaves, and branches, while they are green, are of a good use in the ulcers and putrid sores of the mouth and throat, and of the quinsey, and likewise to heal other fresh wounds and sores; but the flowers and fruit unripe are very binding, and so profitable for the bloody flux, lasks, and are a fit remedy for spitting of blood. Either the decoction of the powder or of the root taken, is good to break or drive forth gravel and the stone in the reins and kidneys. The leaves and brambles, as well green as dry, are exceeding good lotions for sores in the mouth, or secret parts. The decoction of them, and of the dried branches, do much bind the belly and are good for too much flowing of women's courses; the berries of the flowers are a powerful remedy against the poison of the most venomous serpents; as well drank as outwardly applied, helps the sores of the fundament and the piles; the juice of the berries mixed with the juice of mulberries, do bind more effectually, and helps all fretting and eating sores and ulcers wheresoever. The distilled water of the branches, leaves, and flowers, or of the fruit, is very pleasant in taste, and very effectual in fevers and hot distempers of the body, head, eyes, and other parts, and for the purposes aforesaid. The leaves boiled in lye, and the head washed therewith, heals the itch and running sores thereof, and makes the hair black. The powder of the leaves strewed on cankers and running ulcers, wonderfully helps to heal them. Some use to condensate the juice of the leaves, and some the juice of the berries, to keep for their use all the year, for the purposes aforesaid. (Nicholas Culpeper (1616-54) The Complete Herbal, 1850.) 